\title{
Sistem Antrian Single Channel - Multiple Phase dalam Meningkatkan Pelayanan Pembayaran Pajak Kendaraan Bermotor di Kantor Sistem Administrasi Manunggal Satu Atap (SAMSAT) Kota Palu
}

\author{
Single Channel - Multiple Phase on Waiting Line System in Improving \\ Motor Vehicle Tax Payment Services at the Vehicle Document Registration \\ Center (SAMSAT) of Palu City
}

\author{
F.A. Mukarrama*), Nur'Eni, Fadjryani \\ Program Studi Statistika, Fakultas Matematika dan Ilmu Pengetahuan Alam
}

\begin{abstract}
Waiting line system is a set of customers, public servants, and a rule that governs the services for the customers. A waiting line is formed when a number of customers exceed the service capacity available. It happens at the vehicle document registration center (SAMSAT) of Palu city where the long waiting line occurs due to being the motor vehicle tax payment center in the area of Palu city that the researcher was interested in analyzing the waiting line system at the vehicle document registration center (SAMSAT) of Palu city in which the type used was Single Channel - Multiple Phase. In this research, the method used was matching test of the Single Channel - Multiple Phase waiting line model in which the data of arrival time and service time were tested by using Kolmogorov-Smirnov test. Based on the research findings, it is found that the waiting line system of SAMSAT of Palu City is $M / M / 3$ : FCFS $/ \infty / \infty$, and the performance measurement gained in the waiting line system of the motor vehicle tax payment at SAMSAT office of Palu city, both done through manual calculation and done with WINQSB package, reveals the result which is not much different where the average of service time spent by taxpayers exceeded the time limit of service time set, namely 30 minutes, thus to decrease the level of density of the taxpayers and to make the service time efficient, SAMSAT parties need to make improvement on waiting line system by increasing the number of public servants.
\end{abstract}

Keywords: Waiting Line System, Single Channel- Multiple Phase, Performance Measuremen 


\section{ABSTRAK}

Sistem antrian adalah suatu himpunan pelanggan, pelayan, dan suatu aturan yang mengatur pelayanan kepada pelanggan. Antrian terbentuk jika banyaknya yang akan dilayani melebihi kapasitas layanan yang tersedia. Hal ini terjadi di Kantor SAMSAT kota Palu yang sering mengalami kasus antrian panjang karena merupakan pusat pembayaran pajak kendaraan bermotor di wilayah kota Palu. Sehingga peneliti tertarik untuk menganalisis sistem antrian di Kantor SAMSAT Kota Palu yang berjenis Single Channe - Multiple Phase. Dalam penelitian ini metode yang digunakan adalah uji kecocokan model antrian jalur tunggal dengan beberapa tahap pelayanan di mana data waktu kedatangan dan data waktu pelayanan di uji menggunakan uji Kolmogorov-Smirnov. Hasil penelitian ini adalah model sistem antrian SAMSAT kota Palu yaitu M/M/3 : FCFS/ $/ \infty$ dan ukuran kinerja yang diperoleh dalam sistem antrian pembayaran pajak kendaraan di Kantor SAMSAT kota Palu baik melalui perhitungan secara manual maupun menggunakan paket WINQSB menunjukkan hasil yang tidak jauh berbeda di mana rata-rata waktu pelayanan yang dihabiskan wajib pajak melebihi dari pada batas waktu pelayanan yang telah ditetapkan yaitu 30 menit sehingga untuk mengurangi tingkat kepadatan wajib pajak serta mengefesienkan waktu pelayanan maka pihak SAMSAT perlu melakukan perbaikan sistem antrian dengan melakukan penambahan jumlah server

\section{Kata Kunci: Sistem Antrian, Single Channel- Multiple Phase, Ukuran Kinerja}

\section{LATAR BELAKANG}

UU No 25 Tahun 2009 Pasal 1 tentang Pelayanan Publik, menyebutkan bahwa pengertian pelayanan publik adalah kegiatan atau rangkaian kegiatan dalam rangka pemenuhan kebutuhan pelayanan sesuai dengan peraturan perundangundangan bagi setiap warga negara dan penduduk atas barang, jasa, dan/atau pelayanan administratif yang disediakan oleh penyelenggara pelayanan publik. Kualitas pelayanan dapat dilihat dan dirasakan langsung oleh masyarakat dan hal ini dapat dinilai langsung oleh masyarakat pada bagian pelayanan (Artiguna dkk., 2014).
SAMSAT merupakan unit pelayananan publik dalam menyelenggarakan registrasi dan identifikasi kendaraan bermotor berdasarkan ketentuan Pasal 67 ayat (1) Undang-Undang Nomor 22 tahun 2009 tentang Lalu Lintas dan Angkutan Jalan. SAMSAT melayani pembayaran Pajak Kendaraan Bermotor (PKB), Bea Balik Nama Kendaraan Bermotor (BBNKB), dan pembayaran Sumbangan Wajib Dana Kecelakaan Lalu Lintas (SWDKLL).

Antrian pembayaran Pajak Kendaraan Bermotor (PKB) di SAMSAT Kota Palu merupakan pusat tempat pembayaran pajak kendaraan bermotor di wilayah Kota Palu dimana setiap hari begitu banyaknya 
masyarakat yang melakukan pembayaran pajak. Hal ini disebabkan karena sudah adanya istilah tanggal jatuh tempo pembayaran, sehingga mengakibatkan terjadinya antrian. Kepuasan wajib pajak dalam memperoleh pelayanan yang diberikan oleh pegawai kantor SAMSAT cenderung rendah. Hal ini salah satunya dikatakan Wakapolda Sulteng, Kombes Pol Gede Sugianyar Dwi Putra yang melakukan sidak ke kantor SAMSAT kota Palu, beliau melihat kinerja pegawai penjaga loket yang kurang atau tidak sesuai dengan SOP (standar operasional prosedur). Salah satunya adalah pegawai yang melayani wajib pajak untuk satu orang waktu yang dipergunakan lebih dari 30 menit padahal tertulis dengan jelas bahwa waktu pengurusan khusus pembayaran pajak paling lama sekitar 30 menit sehingga menyebabkan antrian yang panjang. (www.suarasulteng.com, Senin, 16 Februari 2015).

Menurut Siagian (2006), sistem antrian adalah himpunan pelanggan, server beserta aturan yang mengatur antara kedatangan pelanggan dan pelayanannya. Antrian terjadi ketika pelanggan yang datang ke suatu pelayanan melebihi kapasitas pelayanan yang tersedia (Ersyad dan Dodi, 2010). Untuk memberikan kepuasan pelanggan, sebuah sistem selalu berusaha memberikan pelayanan yang terbaik. Pelayanan yang terbaik diantaranya adalah memberikan pelayanan yang cepat sehingga pelanggan tidak dibiarkan menunggu terlalu lama. Pelayanan secara cepat dan tanggap sangat penting dilakukan guna mewujudkan kualitas pelayanan yang maksimal, efektif, dan efisien, sehingga para wajib pajak dapat terlayani dengan baik tanpa banyak meluangkan waktu dalam antrian.

Oleh sebab itu, untuk mengatasi masalah yang berkaitan dengan antrian tersebut, dapat dilakukan analisis sistem pelayanan pembayaran pajak kendaraan bermotor di kantor sistem administrasi manunggal satu atap (SAMSAT) Kota Palu dengan menggunakan konsep teori antrian. Dimana nantinya akan dilakukan pencarian model antrian yang tepat dan efisien melalui suatu kegiatan penelitian, dan selanjutnya akan diperoleh model antrian dan ukuran kinerja sebagai pemecahan masalah, sehingga analisis sistem antrian tersebut diharapkan mampu memberi masukan guna peningkatan kualitas pelayanan yang lebih baik.

\section{BAHAN DAN METODE}

Secara umum jenis data yang digunakan adalah data kuantitatif yang meliputi waktu-waktu yang dicatat pada saat proses pelayanan terjadi, sedangkan sumber data yang digunakan dalam penelitian ini adalah data primer yaitu hasil pengukuran secara langsung waktu 
kedatangan wajib pajak. dan waktu wajib pajak dilayani. Hasil wawancara dengan petugas SAMSAT Kota Palu serta data sekunder yang berupa data studi kepustakaan (berbagai teori pendukung yang diambil dari berbagai sumber) dan data profil SAMSAT Kota Palu.

Adapun teknik analisa data yang digunakan dalam penelitian ini adalah teknik jalur tunggal dengan beberapa tahap pelayanan menggunakan metode uji kecocokan model yaitu uji KolmogorovSmirnov kemudian untuk mencari ukuran kinerja digunakan software WINQSB.

Dalam menententukan laju kedatangan wajib pajak digunakan rumus sebagai berikut :

$$
\lambda=\frac{\mathrm{I}}{\mathrm{t}}
$$

Dimana I : Interval waktu kerja

$$
\begin{gathered}
\mathrm{t} \quad \mathrm{J} \text { Jumlah waktu antar } \\
\text { kedatangan }
\end{gathered}
$$

Selanjutnya laju pelayanan wajib pajak ditentukan menggunakan rumus sebagai berikut :

$$
\mu=\frac{N}{t}
$$

Dimana N : Jumlah wajib pajak

$$
\mathrm{t} \text { : Jumlah waktu pelayanan }
$$

Adapun untuk menentukan model antrian digunakan notasi baku sistem antrian yang pertama kali dikemukakan oleh D.G.Kendal dalam bentuk a/b/c , yang dikenal sebagai notasi Kendal. Namun A.M.Lee menambahkan simbol d dan e sehingga menjadi $[\mathrm{a} / \mathrm{b} / \mathrm{c}]$ : [d/e/f] yang disebut notasi kendall-Lee (Anaviroh, 2011).

Penjelasan dari simbol-simbol ini adalah sebagai berikut:

a : Distribusi Kedatangan

b : Distribusi keberangkatan atau waktu pelayanan.

c : Banyaknya pelayanan paralel

d : Disiplin antrian

e : Jumlah maksimum pengantri dalam sistem (antri dan dilayani), dan

f : Jumlah sumber kedatangan

Diketahui bahwa di kantor SAMSAT Kota Palu memiliki sistem antrian jenis single channel - multiple phase yaitu hanya ada satu jalur memasuki sistem pelayanan namun tersedia lebih dari satu (beberapa) tahap pelayanan dan dilaksanakan secara berurutan, olehnya itu untuk menentukan ukuran kinerjanya dilakukan berdasarkan rumus model antrian $\mathrm{M} / \mathrm{M} / 1$ (single channel) yaitu sebagai berikur :

1.Rata-rata jumlah wajib pajak dalam sistem $\left(L_{S}\right)$

$$
L_{s}=\left(\frac{K+1}{2}\right) \frac{\rho}{1-\rho}
$$

2.Rata-rata jumlah wajib pajak dalam antrian $\left(L_{q}\right)$ 


$$
L_{q}=\left(\frac{k+1}{2}\right) \frac{\rho}{1-\rho}-\rho
$$

3.Rata-rata waktu yang dihabiskan seorang wajib pajak dalam sistem $\left(W_{s}\right)$

$$
\mathrm{W}_{S}=\frac{L_{S}}{\lambda}
$$

4.Rata-rata waktu yang dihabiskan seorang wajib pajak dalam antrian $\left(W_{q}\right)$

$$
\mathrm{W}_{q}=\mathrm{W}_{s}-\frac{1}{\mu}
$$

5. Tingkat Kesibukan Server

$$
\mathrm{K}=\rho \times 100 \%
$$

\section{HASIL}

\section{Deskriptif Data}

Orang yang datang untuk melakukan pembayaran pajak kendaraan bermotor di SAMSAT merupakan wajib pajak SAMSAT.

Berdasarkan pengambilan data selama dua minggu mulai dari tanggal $9-21$ Januari 2017 diperoleh pada minggu pertama jumlah wajib pajak yang datang yaitu 906 orang dimana volume wajib pajak terbanyak yang datang terjadi pada hari kamis yaitu sebanyak 201 orang. Volume pelanggan paling sedikit pada hari sabtu sebanyak 55 orang. Sedangkan pada minggu kedua jumlah wajib pajak yang datang yaitu 864 orang dimana volume wajib pajak terbanyak yang datang pada hari selasa sebanyak 193 orang dan volume paling sedikit pada hari sabtu sebanyak 62 orang

\begin{tabular}{|c|c|c|c|c|c|}
\hline Ne. & & Interval & Detcuens & satanga & avertohe \\
\hline & Man rof & Wabte & 1 & 2 & 3 \\
\hline \multirow[t]{4}{*}{ i } & senis. & 0400.10 .00 & $11 \%$ & 20 & 13 \\
\hline & $01 / 2017$ & $10.00-12.00$ & 20 & o) & 83 \\
\hline & & $12.00-14.00$ & to & 32 & 42 \\
\hline & & $1+00-16.00$ & 1) & a1 & $\rightarrow 3$ \\
\hline \multirow[t]{4}{*}{ ? } & Setama & 06.0070 .00 & 7 & 31 & 2 \\
\hline & $101 / 2017$ & 10.00 .12 .00 & 62 & w2 & 96 \\
\hline & & $12.00-14.00$ & $3 x$ & in & 34 \\
\hline & & $1+00.16 .00$ & 12 & 27 & to \\
\hline \multirow[t]{4}{*}{3} & Rabu & $06700=10.00$ & $\pi$ & 13 & 1 \\
\hline & $11 / 1 / 2017$ & $10.00-12.00$ & ob & 63 & $\$ 4$ \\
\hline & & 12.60 .14 .60 & dis & os & ei \\
\hline & & 1400.16 .00 & 3 & 17 & 42 \\
\hline \multirow[t]{4}{*}{ A } & Kamin & 06.0670 .00 & 713 & 26 & 2 \\
\hline & $12 / 2017$ & $10.00-12.00$ & $3+4$ & 01 & $10 \mathrm{~s}$ \\
\hline & & 12.00 .14 .00 & 45 & sit. & 54 \\
\hline & & $1+00.16 .00$ & ' & 29 & 37 \\
\hline \multirow[t]{4}{*}{7} & Kuma! & 64.60 .10 .60 & As & 10 & 2 \\
\hline & $13 / 1 / 2017$ & $10.00-12.00$ & 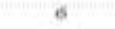 & it & 40 \\
\hline & & 12.00 .14 .00 & $2 y$ & 2 & 3 \\
\hline & & $1+00.16 .00$ & 15 & 35 & 35 \\
\hline \multirow[t]{2}{*}{6} & Nabeu. & कह 6078.60 & 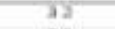 & $\pi$ & 1 \\
\hline & $141 / 2017$ & $10.00-12.00$ & 23 & 52 & 54 \\
\hline \multicolumn{3}{|c|}{ JEMALA } & 608 & 608 & 600 \\
\hline
\end{tabular}

\begin{tabular}{|c|c|c|c|}
\hline \multirow{2}{*}{ No. } & \multirow{2}{*}{ Hari } & \multicolumn{2}{|c|}{ Jumlah Wajib Pajak } \\
\cline { 3 - 4 } & & Minggu Ke-1 & Minggu Ke-2 \\
\hline 1 & Senin & 196 & 184 \\
\hline 2 & Selasa & 178 & 193 \\
\hline 3 & Rabu & 188 & 157 \\
\hline 4 & Kamis & 201 & 185 \\
\hline 5 & Jumat & 88 & 83 \\
\hline 6 & Sabtu & 55 & 62 \\
\hline \multicolumn{2}{|r|}{ Jumlah } & 906 & 864 \\
\hline
\end{tabular}

Tabed 1 Volume Kedatantan Waib Pajak yang Datang di Kantow SAMSAT Kou Palu.

Tabel 2 Frekuensi Kedatangan Wajib Pajak Menurut Waltu (Jam) di Kantor SAMSAT Rota Palu Pada Mingzu ke-1

\begin{tabular}{|c|c|c|c|c|c|}
\hline \multirow{2}{*}{ Ne: } & \multirow{2}{*}{ Hat $\mathrm{T}_{\mathrm{B}}$} & \multirow{2}{*}{$\begin{array}{l}\text { Interval } \\
\text { Waktu }\end{array}$} & \multicolumn{3}{|c|}{ Frokuenai Kadatanuan Fer Loket } \\
\hline & & & 1 & 2 & 3 \\
\hline \multirow[t]{4}{*}{1} & Genin & $0 \$ 0010.00$ & 6: & 27 & 2 \\
\hline & $16 / 1 / 2017$ & $10.00-12.00$ & 60 & 69 & 95 \\
\hline & & $12.00-1400$ & 49 & 24 & 33 \\
\hline & & $14.00 \cdot 1600$ & , & 34 & 3.4 \\
\hline \multirow[t]{4}{*}{2} & Selaka, & 08.0010 .00 & 90 & 14 & 5 \\
\hline & $17 / 12017$ & $10.00-12.00$ & 51 & 103 & 128 \\
\hline & & 12.00 .14 .00 & 31 & as & 22 \\
\hline & & 1400.16 .00 & 1 & (1) & 41 \\
\hline \multirow[t]{4}{*}{3} & Rabu: & $0100-1000$ & 78 & TI & 2 \\
\hline & $18 / 1 / 2017$ & $10.00-12.00$ & 31 & 91 & 04 \\
\hline & & 12.00 .1400 & 46 & 30 & 31 \\
\hline & & $1,4.00 \cdot 16.00$ & 2 & 1ti & 30 \\
\hline \multirow[t]{4}{*}{4} & Kamis: & 08.0070 .00 & 91 & 34 & 4 \\
\hline & $10 / 1 / 2017$ & $10.00-12,00$ & 43 & 100 & $1 * x$ \\
\hline & & $1 \pm .00 .1+00$ & 33 & 24 & 10 \\
\hline & & $14.00-16.00$ & 10 & 27 & 20 \\
\hline \multirow[t]{4}{*}{-5} & Jumat, & $08.00-10.00$ & 33 & 14 & 1 \\
\hline & $20 / 1 / 2017$ & 10.00 .12 .00 & 2 & 43 & eo \\
\hline & & $12,00-14,00$ & 12 & 1 & 2 \\
\hline & & $1+.00-16.00$ & 14 & 23 & 20 \\
\hline \multirow[t]{2}{*}{6} & Sabtu & $08.00+10.00$ & कन & in & 2 \\
\hline & $21 / 1 / 2017$ & $10.00-12.00$ & 18 & 44 & 60 \\
\hline \multicolumn{3}{|c|}{ Jumlah } & 864 & 564 & 504 \\
\hline
\end{tabular}

Ket : Jumlah wailb pajak yang datang di kanter SAMSAT Kota Palu puda minzzu pertamz sebanyak 906 orang yang terbagi dalam empar Interval walan kerja jumiah loker (terver) sebanyak 3 
Tabel 3 Freknensi Kedatangan Wajib Pajak Menurut Wahtu Kerja (Jam)، Kantor SAMSAT Kota Palu Pada Minggu ke-2

Ket = Jumlah wajib pajak yang datang di kantor SAVSAT Kota Palu pad minggu kedua sebanyak $\$ 64$ orang yang terbagi dalam emp interval waktu kerja jumlah loket (server) sebanyak 3

\section{Distribusi Data}

Dalam mengidentifikasi distribusi probabilitas dari data yang diperoleh dilakukan uji kecocokan model yaitu statistik uji Kolmogorov-Smirnov satu sampel dengan menggunakan program SPSS 21.0 for windows. Berdasarkan hasil output yang diperoleh menunjukkan data waktu kedatangan dan data waktu pelayanan masing-masing memiliki nilai $\mathrm{p}$ value $>0,05$ artinya data waktu kedatangan mengikuti distribusi Poisson dan data waktu pelayanan mengikuti distribusi Eksponensial.

\begin{tabular}{|c|c|c|c|c|}
\hline \multicolumn{5}{|c|}{ One-Sample Kolmogorov-Smirnov Test Pada Minggu Pertama } \\
\hline & & LOKET 1 & LOKET 2 & LOKET 3 \\
\hline \multicolumn{2}{|l|}{$\mathrm{N}$} & 22 & 22 & 22 \\
\hline Poisson Parameter ${ }^{\mathrm{a}, \mathrm{b}}$ & Mean & 41.18 & 41.18 & 41.18 \\
\hline \multirow{3}{*}{$\begin{array}{l}\text { Most Extreme } \\
\text { Differences }\end{array}$} & Absolute & .408 & .412 & .321 \\
\hline & Positive & .408 & .412 & .318 \\
\hline & Negative & -.270 & -.264 & -.321 \\
\hline \multicolumn{2}{|c|}{ Kolmogorov-Smimov Z } & 1.912 & 1.931 & 1.504 \\
\hline \multicolumn{2}{|l|}{ Asymp. Sig. (2-tailed) } & .054 & .057 & .082 \\
\hline
\end{tabular}

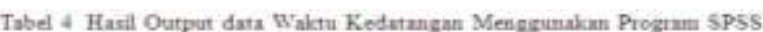
210 for Windews Pada Mirezu Ke-1

Ket : Data frekuensi kedatangm minggu petama di dapattan nilai pelung beturu-turut dari loket satu sampai tige yaitu $0,054,0,057$ dan 0,082 karena nilai pelung yang didaparkan secara ksedurahan lehih besar dari inghat signifikan 0,05 maka dapat disinpulkan bahtra terima $\mathrm{H}_{0}$ rang artinva waltu kedatangan pada minggn petama berdistribusi poisson.

One-Sample Kolmogorov-Smirnov Test Pada Minggu Kedua

\begin{tabular}{|lc|r|r|r|}
\hline & & LOKET 1 & LOKET 2 & LOKET 3 \\
\hline $\mathrm{N}$ & & 22 & 22 & 22 \\
\hline Poisson Parameter & Mean & 39.27 & 39.27 & 39.27 \\
\hline Most Extreme & Absolute & .364 & .475 & .491 \\
Differences & Positive & .364 & .475 & .491 \\
& Negative & -.354 & -.227 & -.303 \\
Kolmogorov-Smimov Z & & 1.705 & 2.227 & 2.303 \\
Asymp. Sig. (2-tailed) & & .071 & .052 & .058 \\
\hline
\end{tabular}

Tabel 5 Hasil Output dara Waktu Kedatangan Nenggunakan Program SPSS 21.0 for Windosss Pada Minggu $\mathrm{Ke}$-2

Ket : Data freknensi kedatangan minggn kedua di daparkan milai peluang berturut-turut dari loket satu sampai tiga yaitu 0,071, 0,052 dan 0,058 karena nilai peluang vang didapatkan secara keseluruhan lebil besar dani tingkat signifikan 0,05 maka dapat disimpulkan bahno terima $\mathrm{H}_{0}$ yang artinva waktu kedatangan pada minggu kedua berdistribusi poisson

\begin{tabular}{|c|c|c|c|c|}
\hline & & LOKET I & LOKET 2 & LOKET 3 \\
\hline \multicolumn{2}{|l|}{$\mathrm{N}$} & 906 & 906 & 906 \\
\hline Poisson Parameter:" & Mean & $0: 01: 04$ & $0: 00: 54$ & $0: 00.42$ \\
\hline \multirow{3}{*}{$\begin{array}{l}\text { Most Extreme } \\
\text { Differences }\end{array}$} & Absolute & 549 & 405 & 472 \\
\hline & Positive & - 349 & 495 & 472 \\
\hline & Negative & $=189$ & $-"-222$ & - \\
\hline \multicolumn{2}{|c|}{ Kolmogorov-Smirnov Z } & 16.519 & 14.8900 & 14.193 \\
\hline \multicolumn{2}{|l|}{ Asymp sig (2-tailed) } & .706 & 323 & 316 \\
\hline
\end{tabular}

Tabel 6 Hasil Output data Waktu Pelayanan Menggunakan Program SPSS 21.0 for Windows Pada Minggu Ke-1

Set: Data waktu pelavanan minggu pertama di dapatkan nilai peluang berturut-turut dari loket satu sampai tiga yaitu $0,706,0,523$ dan 0,516 karena nilai peluang yang didapatkan secara keseluruhan lebih besar dari tingkat signifikan 0,05 maka dapat disimpalkan bahwa terima $\mathrm{H}_{0}$ yang artinya waktu pelayanan pada minggu pertama berdistribusi eksponensial

\begin{tabular}{|} 
One-Sample Kolmogorov-Smimov Test Pada Minggu Kedua \\
\hline & & LOKET 1 & LOKET 2 & LOKET 3 \\
\hline $\mathrm{N}$ & 864 & 864 & 864 \\
Exponential parameter. ${ }^{\mathrm{a}, \mathrm{b}}$ & Mean & $0: 01: 06$ & $0: 00: 55$ & $0: 00: 49$ \\
\hline Most Extreme & Absolute & .164 & .214 & .228 \\
Differences & Positive & .112 & .081 & .098 \\
& Negative & -.164 & -.214 & -.228 \\
Kolmogorov-Smirnov Z & 4.819 & 6.286 & 6.696 \\
Asymp. Sig. (2-tailed) & .315 & .411 & .420 \\
\hline
\end{tabular}

Tabel 7 Hail Ourput data Waktu Pelayanan Menggunakan Program SPSS 21.0 for Windows Pada Minggu Ke-2

Ket : Data waktu pelayanan minggu kedua di dapatkan nilai peluang bertunat-tunt dari loket satu sampai tiga yaitu $0,315,0,411$ dan 0.420 karenu nilaj peluang yang didapatkan secara keselunuhan lebih besar dari tingkat signifikan 0,05 maka dapat disimpolkan balswa terima $\mathrm{H}_{6}$ yass artinya wakts pelayanan pada minggu kedua berdistribusi ekmonensia?

\section{Penentuan Model Antrian}

Dari hasil pengujian kecocokan model distribusi data penelitian waktu kedatangan dan waktu pelayanan dimana proses antriannya berjenis single channel multiple phase maka disimpulkan bahwa waktu kedatangan mengikuti distribusi Poisson, waktu pelayanan mengikuti 
distribusi Eksponensial, terdapat 3 server yaitu loket pendaftaran, loket pembayaran pajak dan loket pengesahan STNK, disiplin antrian FCFS dan kapasitas antrian tidak terbatas. Maka disimpulkan bahwa model antrian yang terdapat di Kantor SAMSAT Kota Palu yaitu M/M/3: FCFS/ $\infty / \infty$.

\section{Penentuan Laju Kedatangan dan}

\section{Laju Pelayanan}

Laju kedatangan ditentukan dengan menggunakan persamaan (2.1) sehingga diperoleh pada minggu pertama laju kedatangannya berturut-turut dari loket 1 sampai 3 yaitu 0,195/ jam , 0,190/jam dan 0,1866/jam. Sedangkan pada minggu kedua laju kedatangannya berturut-turut dari loket 1 sampai 3 yaitu 0,196/jam , 0,238/jam dan 0,212/jam.

Laju pelayanan ditentukan dengan menggunakan persamaan (2.2) sehingga, sehingga diperoleh laju pelayanan pada minggu pertama berturut-turut dari loket 1 sampai 3 yaitu 56 orang, 66 orang dan 88 orang. Sedangkan pada minggu kedua laju pelayanannya berturut-turut dari loket 1 sampai 3 yaitu 68 orang, 65 orang dan 73 orang.

\section{Hasil Ukuran Kinerja Analisis Sistem Antrian}

Berdasakan hasil pengamatan yang dilakukan selama 1 minggu mulai dari hari senin 09 januari 2017 sampai hari sabtu tanggal 14 januari 2017 diperoleh jumlah wajib pajak sebanyak 906 orang.

Adapun ukuran kinerjanya sebagai berikut :

a. Loket 1

Rata-rata jumlah wajib pajak yang berada dalam sistem antrian $\left(L_{S}\right)$ sebanyak 429 orang, rata-rata jumlah wajib pajak yang berada dalam antrian $\left(L_{q}\right)$ sebanyak 428 orang. rata-rata waktu yang dihabiskan seorang wajib pajak dalam sistem (waktu menunggu dan dilayani) $\left(W_{s}\right)$ sebesar 9,6 jam dan rata-rata waktu yang dihabiskan seorang wajib pajak dalam antrian $\left(W_{q}\right)$ sebesar 9,5 jam.

b. Loket 2

Rata-rata jumlah wajib pajak yang berada dalam sistem antrian $\left(L_{S}\right)$ sebanyak 215 orang, rata-rata jumlah wajib pajak yang berada dalam antrian $\left(L_{q}\right)$ sebanyak 214 orang, rata-rata waktu yang dihabiskan seorang wajib pajak dalam sistem (waktu menunggu dan dilayani) $\left(W_{s}\right)$ sebesar 4,98 jam dan rata-rata waktu yang dihabiskan seorang wajib pajak dalam antrian $\left(W_{q}\right)$ sebesar 4,96 jam.

c. Loket 3

Rata-rata jumlah wajib pajak yang berada dalam sistem antrian $\left(L_{S}\right)$ sebanyak 105 orang, rata-rata jumlah wajib pajak yang berada dalam antrian $\left(L_{q}\right)$ sebanyak 104 orang. rata-rata waktu yang dihabiskan seorang wajib pajak dalam sistem (waktu 
menunggu dan dilayani) $\left(W_{s}\right)$ sebesar 2,5 jam dan rata-rata waktu yang dihabiskan seorang wajib pajak dalam antrian $\left(W_{q}\right)$ sebesar 2,4 jam.

\begin{tabular}{|c|c|c|c|c|c|c|c|c|}
\hline $\mathrm{N}_{0}$ & Fixi & Loket & $b_{8}$ & 4 & $W_{r}$ & $\mathbb{W}_{F}$ & 8 & $w$ \\
\hline \multirow[t]{3}{*}{1} & \multirow[t]{3}{*}{ Sen } & 1 & 97 & 96 & 23 & 2.2 & 77.55 & $20.5 \%$ \\
\hline & & 2 & III & 110 & 24 & 23 & 81.75 & 15.35 \\
\hline & & 3 & 65 & 64 & 1.43 & 1,41 & 7235 & 27,78 \\
\hline \multirow[t]{3}{*}{2} & \multirow[t]{3}{*}{ Strasa } & 1 & 45 & 41 & 1.06 & 1,04 & 63.25 & $31,5=$ \\
\hline & & 2 & 27 & 86 & 0,59 & 0,56 & 9415 & 45,95 \\
\hline & & 3 & 35 & 34 & 0,70 & б, & 6025 & 19,83 \\
\hline \multirow[t]{3}{*}{3} & \multirow[t]{3}{*}{ Restu } & 1 & 40 & 39 & 0,79 & $0, \pi$ & 6235 & $37,1 \mathrm{~s}$ \\
\hline & & 2 & 35 & 37 & 0.86 & 0,84 & 51.28 & 38.54 \\
\hline & & 3 & 19 & 13 & 0.41 & 0,40 & 43.95 & 56.23 \\
\hline \multirow[t]{3}{*}{4} & \multirow[t]{3}{*}{$\mathrm{K}$ enir } & 1 & 23 & 22 & 0,57 & 0,56 & 47.925 & 52985 \\
\hline & & 2 & 34 & 33 & 0,70 & 0,69 & $37.14 \mathrm{~s}$ & $42.56 \%$ \\
\hline & & 3 & 36 & 25 & 0.56 & 0,54 & 50.55 & $49.5 \%$ \\
\hline \multirow[t]{3}{*}{5} & \multirow[t]{3}{*}{ Semer } & 1 & 103 & 162 & 2,6 & 2,5 & $90 \%$ & 205 \\
\hline & & 2 & 26 & 25 & 0.85 & 0,86 & $59 \%$ & $31 \%$ \\
\hline & & 3 & 5 & 7 & 0,19 & 0,17 & 3155 & 51,53 \\
\hline \multirow[t]{3}{*}{6} & \multirow[t]{3}{*}{5 sban } & $T$ & 12 & II & 0,5 & 0.7 & $51.5 \mathrm{~s}$ & $38.2 \mathrm{~s}$ \\
\hline & & 2 & 4 & 3 & 0.21 & 0.18 & $35.4 \mathrm{~s}$ & 63.4\% \\
\hline & & 3 & 3 & 2 & 0,06 & $Q, 05$ & $145 \mathrm{~s}$ & $855 \mathrm{~s}$ \\
\hline
\end{tabular}

Tabel 8 Hasil Ukutan Kinerja Sistem Antrian di Kantor SAMSAT Kota Palu pada Minggu Pertama dari Hari Senin - Sabtu

Ket - Tabel hasit ukuran kineria pada mingeu pertama rata-rata waktu yang dihabiskan wajiblo pajak per harinve baik waktu menunggu dalam antrian maupun dalant sistem yaitu $=0,5$ jams. Hal itu menurijukkan bakwa waktu pelayanan di kantor SAMSAT belum efisien dan masih melebilhi dari batas waktu yang ditetapkan sesuai SOP (Standar Operasional Prosedur).

\begin{tabular}{|c|c|c|c|c|c|c|c|c|}
\hline No. & Hari & Loket & $\begin{array}{c}L_{s} \\
\text { (Orang) }\end{array}$ & $\begin{array}{c}L_{Q} \\
\text { (Orang) }\end{array}$ & $\begin{array}{c}W_{s} \\
(\mathrm{Jam})\end{array}$ & $\begin{array}{c}W_{q} \\
(\mathrm{Jam})\end{array}$ & K & W \\
\hline \multirow[t]{3}{*}{1} & \multirow[t]{3}{*}{ Senin } & 1 & 78 & 77 & 1,51 & 1,50 & $77 \%$ & $23 \%$ \\
\hline & & 2 & 29 & 28 & 0,58 & 0,57 & $55,2 \%$ & $44,8 \%$ \\
\hline & & 3 & 25 & 24 & 0,53 & 0,52 & $51,1 \%$ & $48,9 \%$ \\
\hline \multirow[t]{3}{*}{2} & \multirow[t]{3}{*}{ Selasa } & 1 & 55 & 54 & 1,16 & 1,15 & $69,2 \%$ & $30,8 \%$ \\
\hline & & 2 & 36 & 35 & 0,62 & 0,61 & $59,3 \%$ & $40,7 \%$ \\
\hline & & 3 & 58 & 57 & 1,10 & 1,09 & $70,4 \%$ & $29,6 \%$ \\
\hline \multirow[t]{3}{*}{3} & \multirow[t]{3}{*}{ Rabu } & 1 & 29 & 28 & 0,7 & 0,6 & $59,2 \%$ & $40,8 \%$ \\
\hline & & 2 & 30 & 29 & 0,6 & 0,5 & $84,5 \%$ & $15,5 \%$ \\
\hline & & 3 & 26 & 25 & 0,60 & 0,59 & $56,1 \%$ & $43,9 \%$ \\
\hline \multirow[t]{3}{*}{4} & \multirow[t]{3}{*}{ Kamis } & 1 & 87 & 86 & 1,98 & 1,96 & $78,8 \%$ & $21,2 \%$ \\
\hline & & 2 & 51 & 49 & 0,95 & 0,93 & $78,6 \%$ & $21,4 \%$ \\
\hline & & 3 & 72 & 71 & 1,56 & 1,55 & $75,4 \%$ & $26,4 \%$ \\
\hline \multirow[t]{3}{*}{5} & \multirow[t]{3}{*}{ Jumat } & 1 & 77 & 76 & 2,44 & 2,41 & $87,5 \%$ & $12,5 \%$ \\
\hline & & 2 & 11 & 10 & 0,25 & 0,24 & $50 \%$ & $50 \%$ \\
\hline & & 3 & 8 & 7 & 0,24 & 0,23 & $43,1 \%$ & $56,9 \%$ \\
\hline \multirow[t]{3}{*}{6} & \multirow[t]{3}{*}{ Sabtul } & 1 & 11 & 10 & 0,80 & 0,76 & $57,6 \%$ & $42,4 \%$ \\
\hline & & 2 & 4 & 3 & 0,20 & 0,18 & $28,7 \%$ & $71,3 \%$ \\
\hline & & 3 & 3 & 2 & 0,11 & 0,10 & $21,3 \%$ & $78,7 \%$ \\
\hline
\end{tabular}

Tabd 9 Hail Ulouran Kineju Sinten Antrian de Kintor SAMSAT Kota Pahs pada Minzzu Kedua dasi Hari Senin + Sabei
Kes - Tabel hail ukuran kineji pada minggs kedua rata cata waktu jang Cihabiskan wajb pajak per turiaya bak waktu menunggu dalum

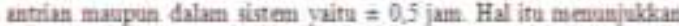
buhwa waktu pelayanan di kantor SANSAT belum efilien dan masil melebiahi dari batas wakn yang ditetapkan senui SOP (Standar Operasional Prosedert)

\section{Tingkat Kesibukan Server}

Nilai $\mathrm{K}$ yang didapatkan rata-rata menunjukkan tingkat kesibukan server dapat dikatakan cukup sibuk dalam melayani wajib pajak.

\section{Analisis Data Menggunakan Software WINQSB}

Berikut langkah - langkah penggunaan software WINQSB untuk penyelesaian masalah model antrian Single Channel - Multiple Phase yaitu :

1. Tampilan membuka aplikasi dengan cara klik Start > Program > WinQSB > Queuing Analysis

2. Kemudian, akan muncul tampilan awal dari

WinQSB dan pilih File > New Problem atau klik icon new folder.

3. Akan muncul Problem Spesification. Pada kolom entry format pilih menu Simple M/M system.

4. Setelah itu muncul kotak dialog Simple M/M System. Lalu isi data berikut :

Namber of servers (Jumlah Server)

Service rate (laju pelayanan $)=1 / \mu$

Arrival rate $($ Laju Kedatangan $)=1 / \lambda$

5. Pilih solve and analyst > solve the performance

6. Hasil

Sistem Antrian Single Channel - Multiple Phase dalam Meningkatkan Pelayanan Pembayaran Pajak Kendaraan Bermotor di SAMSAT Kota Palu 
Adapun hasil output diperoleh hasil perhitungan menggunakan software WINQSB menunjukkan hasil yang sama dengan perhitungan menggunakan formula ukuran kinerja secara manual sebelumnya.

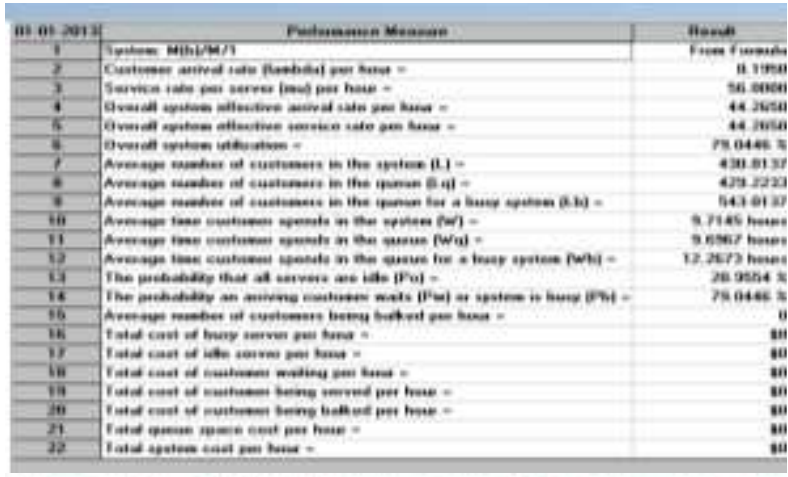

Gambar 1 Outpur MLNQSB dari sistem antrian loket I pada mingsa pera

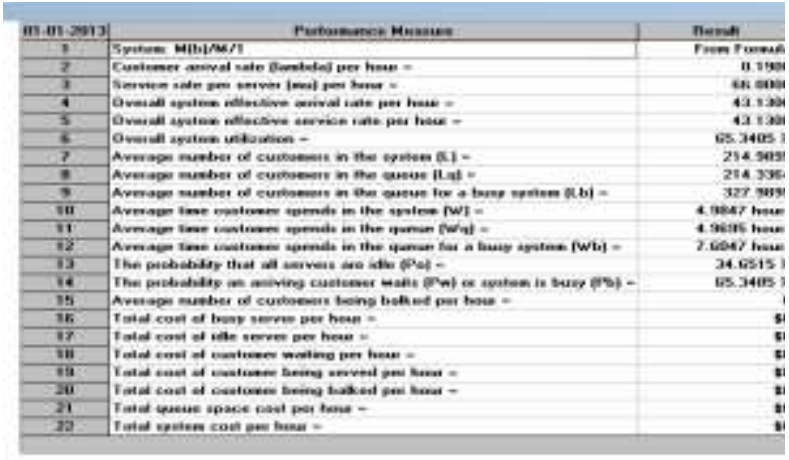

Gambar 2 Ourput 1FZQSB dar sistem antrian loket 2 pads mingza pera

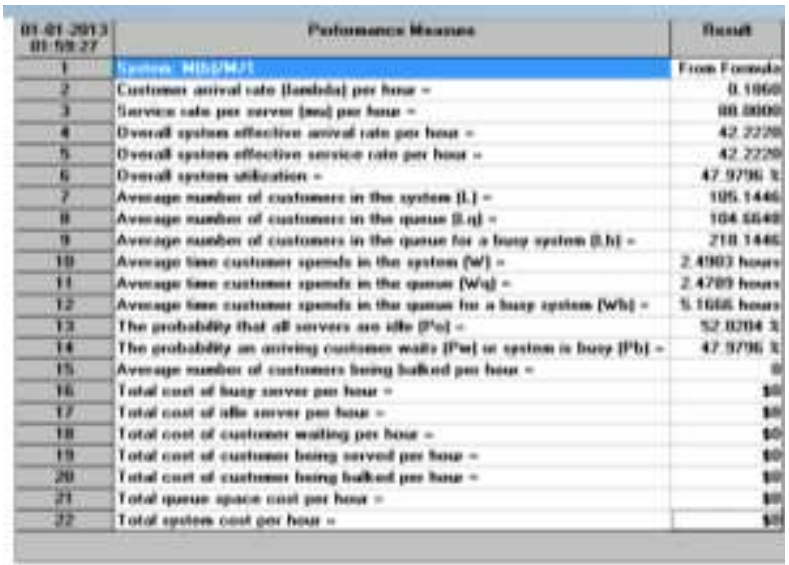

Gambar 3 Output IINQSB dari sistem autrian loket 3 pada minggu pertama

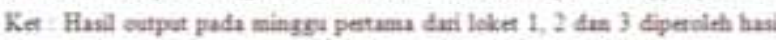

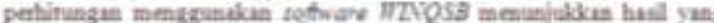

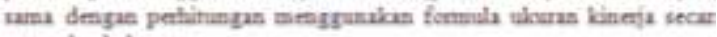
muraal setehumnya.

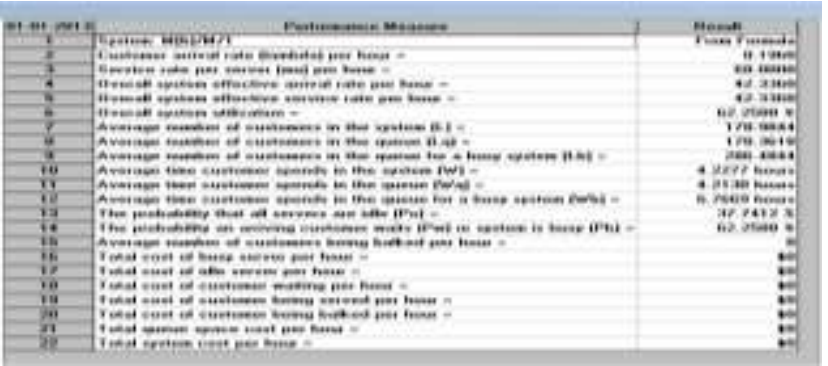

Gambar 4 Output WINQSB dari sistem antrian loket 1 pada minggu kedua

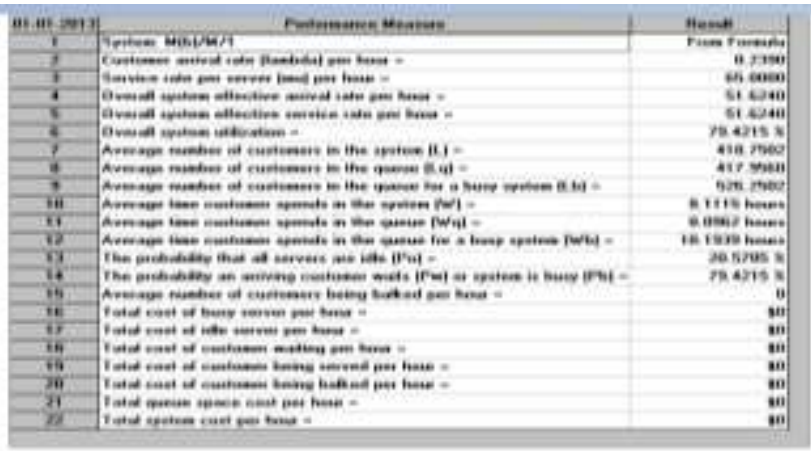

Gambar 5 Output WINQSB dari sistem antrian loket 2 pada minggu kedua

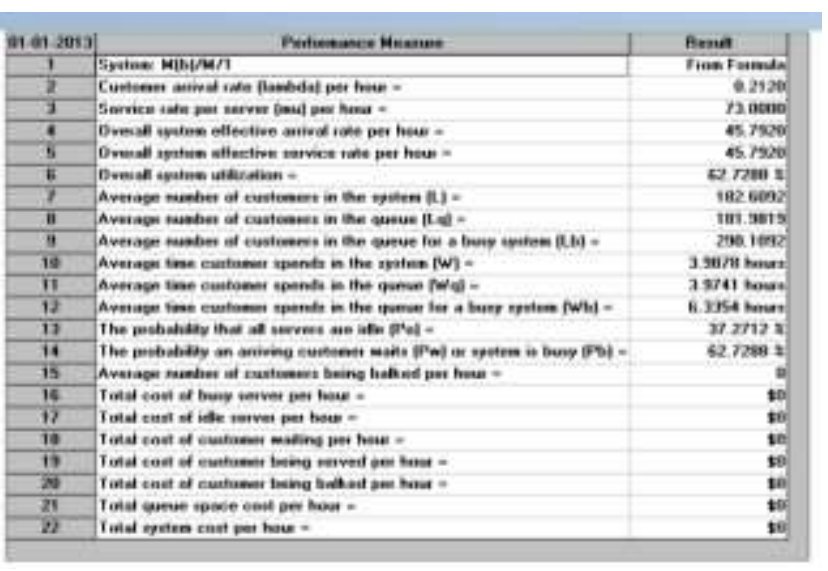

Gambar 6 Output WINQSB dari sistem antrian loket 3 pada minggu kedua

Ket : Hasit output pada minggu kedua dari loket 1,2 dan 3 diperoleh hasil

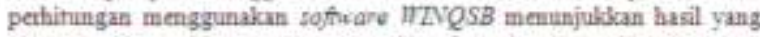
sama dengan perhitungan mengzunakan formula ukuran kineja secara mantal sebelumany.

\section{PEMBAHASAN}

\section{a. Laju Kedatangan}

Laju kedatangan ditentukan dengan menggunakan persamaan (2.1) sehingga,

- Minggu Pertama :

$$
\begin{array}{ll}
\text { Loket } 1 & \lambda=\frac{\mathrm{I}}{\mathrm{t}}=\frac{4}{20: 33: 35}=\frac{4}{20,5 \mathrm{Jam}}=0,195 / \mathrm{Jam} \\
\text { Loket } 2 & \lambda=\frac{\mathrm{I}}{\mathrm{t}}=\frac{4}{20: 59: 00}=\frac{4}{21 \mathrm{Jam}}=0,190 / \mathrm{Jam} \\
\text { Loket } 3 & \lambda=\frac{\mathrm{I}}{\mathrm{t}}=\frac{4}{21: 21: 48}=\frac{4}{21,35 \mathrm{Jam}}=0,186 / \mathrm{Jam}
\end{array}
$$


- Minggu Kedua :

Loket $1 \quad \lambda=\frac{\mathrm{I}}{\mathrm{t}}=\frac{4}{20: 24: 17}=\frac{4}{20,4 \mathrm{Jam}}=0,196 / \mathrm{Jam}$

Loket $2 \lambda=\frac{\mathrm{I}}{\mathrm{t}}=\frac{4}{16: 46: 22}=\frac{4}{16,7 \mathrm{Jam}}=0,239 / \mathrm{Jam}$

Loket $3 \lambda=\frac{\mathrm{I}}{\mathrm{t}}=\frac{4}{18: 52: 44}=\frac{4}{18,8 \mathrm{Jam}}=0,212 / \mathrm{Jam}$

\section{b. Laju Pelayanan}

Laju pelayanan ditentukan dengan menggunakan persamaan (2.2) sehingga,

- Minggu Pertama :

Loket $1 \mu=\frac{\mathrm{N}}{\mathrm{t}}=\frac{906}{16: 10: 55}=\frac{906}{16.2 \mathrm{Jam}}=55,9=56$ Orang

Loket $2 \mu=\frac{\mathrm{N}}{\mathrm{t}}=\frac{906}{13: 40: 53}=\frac{906}{13,7 \mathrm{Jam}}=66,1=66$ Orang

Loket $3 \mu=\frac{\mathrm{N}}{\mathrm{t}}=\frac{906}{10: 42: 19}=\frac{906}{10,7 \mathrm{Jam}}=84,7=88$ Orang

- Minggu Kedua :

Loket $1 \mu=\frac{\mathrm{N}}{\mathrm{t}}=\frac{864}{12: 44: 49}=\frac{864}{12,73 \mathrm{Jam}}=67,8 \approx 68$ Orang

Loket $2 \mu=\frac{\mathrm{N}}{\mathrm{t}}=\frac{864}{13: 13: 28}=\frac{864}{13,21 \mathrm{Jam}}=65,4 \approx 65$ Orang

Loket $3 \mu=\frac{\mathrm{N}}{\mathrm{t}}=\frac{864}{11: 51: 26}=\frac{864}{11,85 \mathrm{Jam}}=72,9 \approx 73$ Orang

\section{c. Hasil Ukuran Kinerja Analisis Sistem}

\section{Antrian}

1.Rata-rata jumlah wajib pajak dalam sistem $\left(L_{S}\right)$

- Loket 1

$L_{S}=\left(\frac{k+1}{2}\right) \frac{\rho}{1-\rho}=\left(\frac{227+1}{2}\right) \frac{0,790}{1-0,790}=\left(\frac{228}{2}\right) \frac{0,790}{0,21}=428,8 \approx 429$

- Loket 2

$L_{S}=\left(\frac{k+1}{2}\right) \frac{\rho}{1-\rho}=\left(\frac{227+1}{2}\right) \frac{0,653}{1-0,653}=\left(\frac{228}{2}\right) \frac{0,653}{0,347}=214,5 \approx 215$

- Loket 3

$L_{S}=\left(\frac{k+1}{2}\right) \frac{\rho}{1-\rho}=\left(\frac{227+1}{2}\right) \frac{0,479}{1-0,479}=\left(\frac{228}{2}\right) \frac{0,479}{0,521}=104,8 \approx 105$
Jadi, nilai $L_{S}$ pada minggu pertama berturut-turut dari loket 1, 2 dan 3 sebesar 429 orang, 215 orang dan 105 orang menunjukkan jumlah rata-rata wajib pajak pada yang berada dalam sistem antrian.

2.Rata-rata jumlah wajib pajak dalam $\operatorname{antrian}\left(L_{q}\right)$

- Loket 1

$$
\begin{aligned}
L_{q}=\left(\frac{k+1}{2}\right) \frac{\rho}{1-\rho}-\rho & =\left(\frac{227+1}{2}\right) \frac{0,790}{1-0,790}-0,790 \\
& =\left(\frac{228}{2}\right) \frac{0,790}{0,21}-0,790 \\
& =428,8-0,790=428,01 \approx 428
\end{aligned}
$$

- Loket 2

$$
\begin{aligned}
L_{q}=\left(\frac{k+1}{2}\right) \frac{\rho}{1-\rho}-\rho & =\left(\frac{227+1}{2}\right) \frac{0,653}{1-0,653}-0,653 \\
& =\left(\frac{228}{2}\right) \frac{0,653}{0,347}-0,653 \\
& =214,5-0,653=213,8 \approx 214
\end{aligned}
$$

- Loket 3

$$
\begin{aligned}
L_{q}=\left(\frac{k+1}{2}\right) \frac{\rho}{1-\rho}-\rho & =\left(\frac{227+1}{2}\right) \frac{0,479}{1-0,479}-0,479 \\
& =\left(\frac{228}{2}\right) \frac{0,479}{0,521}-0,479 \\
& =104,8-0,479=104,3 \approx 104
\end{aligned}
$$

Jadi, nilai $L_{q}$ pada minggu pertama berturut-turut dari loket 1, 2 dan 3 sebesar 428 orang, 214 orang dan 104 orang menunjukkan jumlah rata-rata wajib pajak pada yang berada dalam antrian.

3.Rata-rata waktu yang dihabiskan seorang wajib pajak dalam sistem $\left(W_{s}\right)$

- Loket 1

$$
\begin{aligned}
W_{S} & =\frac{1}{2 \mu(1-\rho)}\left[\frac{\mathrm{k}+\mathrm{k}^{2}}{\mathrm{k}}\right] \\
& =\frac{1}{2.56(1-0,790)}\left[\frac{227+227^{2}}{227}\right] \\
& =\frac{1}{23,52} \frac{51.756}{227}=(0,042)(228)=9,57 \mathrm{jam}
\end{aligned}
$$


- Loket 2

$$
\begin{aligned}
W_{S} & =\frac{1}{2 \mu(1-\rho)}\left[\frac{\mathrm{k}+\mathrm{k}^{2}}{\mathrm{k}}\right] \\
& =\frac{1}{2.66(1-0,653)}\left[\frac{227+227^{2}}{227}\right] \\
& =\frac{1}{45,804} \frac{51.756}{227}=(0,0218)(228)=4,97 \mathrm{jam} \approx 5 \mathrm{jam}
\end{aligned}
$$

- Loket 3

$$
\begin{aligned}
W_{S} & =\frac{1}{2 \mu(1-\rho)}\left[\frac{\mathrm{k}+\mathrm{k}^{2}}{\mathrm{k}}\right] \\
& =\frac{1}{2.88(1-0,479)}\left[\frac{227+227^{2}}{227}\right] \\
& =\frac{1}{91,696} \frac{51.756}{227}=(0,0109)(228)=2,48 \mathrm{jam} \approx 2,5 \mathrm{jam}
\end{aligned}
$$

Jadi, nilai $W_{S}$ pada minggu pertama berturut-turut dari loket 1, 2 dan 3 sebesar 9,6 jam, 5 jam dan 2,5 jam menunjukkan rata-rata waktu yang dihabiskan seorang wajib pajak dalam sistem (waktu menunggu dan dilayani).

4.Rata-rata waktu yang dihabiskan seorang wajib pajak dalam antrian $\left(W_{q}\right)$

- Loket 1

$$
\begin{aligned}
W_{q} & =\frac{1}{2 \mu(1-\rho)}\left[\frac{\mathrm{k}^{2}-k(1-2 \rho)}{\mathrm{k}}\right] \\
& =\frac{1}{2.56(1-0,790)}\left[\frac{227^{2}-227(1-2(0.790))}{227}\right] \\
& =\frac{1}{112(0,21)}\left[\frac{51.529-227(-0,58)}{227}\right] \\
& =\frac{1}{23,52}\left[\frac{51.529+131,66}{227}\right]=(0.042)(227,58)=9,55 \mathrm{jam}
\end{aligned}
$$

- Loket 2

$$
\begin{aligned}
W_{q} & =\frac{1}{2 \mu(1-\rho)}\left[\frac{\mathrm{k}^{2}-k(1-2 \rho)}{\mathrm{k}}\right] \\
& =\frac{1}{2.66(1-0,653)}\left[\frac{227^{2}-227(1-2(0.653))}{227}\right] \\
& =\frac{1}{132(0,347)}\left[\frac{51.529-227(-0,306)}{227}\right] \\
& =\frac{1}{45,804}\left[\frac{51.529+69,462}{227}\right]=(0.0218)(227,306)=4,9 \mathrm{jam}
\end{aligned}
$$

- Loket 3

$$
\begin{aligned}
W_{q} & =\frac{1}{2 \mu(1-\rho)}\left[\frac{\mathrm{k}^{2}-k(1-2 \rho)}{\mathrm{k}}\right] \\
& =\frac{1}{2.88(1-0,479)}\left[\frac{227^{2}-227(1-2(0.479))}{227}\right] \\
& =\frac{1}{176(0,521)}\left[\frac{51.529-227(0,042)}{227}\right] \\
& =\frac{1}{91,696}\left[\frac{51.529-9,534}{227}\right]=(0.01090)(226,958)=2,47 \mathrm{jam}
\end{aligned}
$$

Jadi, nilai $W_{q}$ pada minggu pertama berturut-turut dari loket 1, 2 dan 3 sebesar 9,5 jam, 5 jam dan 2,5 jam menunjukkan rata-rata waktu yang dihabiskan seorang wajib pajak dalam antrian.

5. Tingkat Kesibukan Server

- Loket 1

$$
\begin{aligned}
\mathrm{K} & =\rho \times 100 \% \\
& =0,790 \times 100 \%=79,0 \% \approx 79 \%
\end{aligned}
$$

- Loket 2

$$
\begin{aligned}
\mathrm{K} & =\rho \times 100 \% \\
& =0,653 \times 100 \%=65,3 \% \approx 65 \%
\end{aligned}
$$

- Loket 3

$$
\begin{aligned}
\mathrm{K} & =\rho \times 100 \% \\
& =0,479 \times 100 \%=47,9 \% \approx 48 \%
\end{aligned}
$$

Jadi, nilai $\mathrm{K}$ yang didapatkan rata-rata menunjukkan tingkat kesibukan server dapat dikatakan cukup sibuk dalam melayani wajib pajak.

Berdasarkan hasil ukuran kinerja yang diperoleh terlihat bahwa rata-rata waktu yang dihabiskan seorang wajib pajak dalam sistem (waktu menunggu dan dilayani) per harinya diatas dari 0,5 jam dimana hal itu menandakan melebihi waktu pelayanan yang ditetapkan SAMSAT yaitu 30 menit 
sesuai standar operasional pelayanan

(SOP), olehnya itu untuk mengurangi

tingkat kepadatan wajib pajak serta mengefesienkan waktu pelayanan maka pihak SAMSAT perlu melakukan perbaikan sistem antrian dalam meningkatkan pelayanan pembayaran pajak kendaraan bermotor di kota Palu dengan melakukan penambahan jumlah server.

\section{UCAPAN TERIMA KASIH}

Penulis mengucapkan terima kasih tak terhingga dan rasa hormat kepada pihak Kantor SAMSAT Kota Palu baik Polri, Unit Pelaksana Teknis Daerah (UPTD) Badan Pendapatan Daerah (Bapenda) Sulawesi Tengah Wilayah I Kota Palu maupun PT. Jasa Raharja yang telah memperkenankan penulis dalam mengambil data di lapangan.

\section{DAFTAR PUSTAKA}

Siagian, P., 2006, Penelitian Operasional, Universitas Indonesia, Jakarta.

Ersyad, Z. dan Dodi, D., (2010). Identifikasi Model Antrian Pada Antrian Bus Kampus Universitas Andalas Padang., Jurnal Matematika FMIPA UNAND, 1(2), 44-51.

Artiguna, P. P., Sugito., dan Hoyyi, A. (2014). Analisis sistem antrian pada layanan pengurusan paspor di kantor Imigrasi kelas I Semarang. Gaussian, 3(4) (801-810). http://ejournals1.undip.ac.id/index.ph p/gaussian. Di akses 21 Februari 2017. 